\title{
Round: Before the Start of the Long War
}

She knelt in the soil of Rafah, before the armored bulldozer's advancing blade. She wore fluorescent orange so even the gods of the coming war could see her, young woman holding a megaphone aloft in crossed sights of the guard tank. The bulldozer driver had orders-demolish the day's quota of homes and thousand-year-old olive groves that blocked the occupiers' rising wall.

She wore fluorescent orange, reflective stripes brilliant as Joseph's coat as he knelt before his brothers in a pit in the dirt of Dothan. Raising the megaphone like a torch, she rose with earth in the Dy bulldozer's advancing scoop till she was eye-level with its cockpit.

There would be no accident in the guard tank's gun sights, she was eye-to-eye with the $\mathrm{D} 9$ driver.

What did she say, lowering her megaphone to him who had orders to knock down the village doctor's home in the shadow of Gaza guard towers? There would be no accident, but the driver had his orders, dropped his eyes, dropped the bulldozer's blade, her megaphone rolled away as her foot caught in the toothed scoop, she slipped, her shocked comrades in their own fluorescent vests ran toward her screaming No as panic flashed

across her face, brilliant as tracer fire bleeding each night in the Gaza sky. Night in the D9 driver's eye, as thick dirt pushed up by the advancing blade 
poured over her, the 9-ton bulldozer rolled over her. Stopped. Reversed. Rolled back.

Withdrew. Her comrades screaming threw themselves over the broken form they dug from the packed earth's tracks.

Only darkness in her eyes rolled back, blood's shocked petals spread over her face as if to shield her from her own bloodsource as sobbing praying friends cradled her body's ebb and gods of the long war drew back on the village's crumbling doorsteps. No light in the bulldozer driver's eye, who'd witnessed everything from his lofty cockpit: the orange-striped girl tumbling from his sight-level like Joseph

into a pit in Gaza, her blood-brilliant coat delivered unto her father, her mother as the tank's and bulldozer's crushing treads tracked back to the iron wall's perimeter and drove off. No aid for the dying girl as minutes before the ambulance arrived grew to seem years across the iron wall where she went on kneeling in the soil of Rafah.

\author{
Rachel Corrie \\ Rafah, Gaza Strip \\ 16 March 2003
}

